DOI: https://doi.org/10.15407/techned2018.05 $: \underline{057}$

\title{
CONCEPT OF EXPERIMENTAL RESEARCH FOR ELECTRICAL VEHICLE ELECTROMECHANICAL SYSTEMS WITH HYBRID ENERGY STORAGES
}

Journal

Publisher

ISSN

Issue

Pages
Tekhnichna elektrodynamika

Institute of Electrodynamics National Academy of Science of Ukraine 1607-7970 (print), 2218-1903 (online)

No 5, 2018 (September/October)

$57-60$

\section{Authors}

\section{S. Peresada ${ }^{1 \star}$, S. Kovbasa ${ }^{1 * \star}$, Ye. Nikonenko ${ }^{1 * \star}$, S. Bozhko ${ }^{2 \star \star \star \star}$}

1 - National Technical University of Ukraine "Igor Sikorsky Kyiv Polytechnic Institute",

pr. Peremohy, 37, Kyiv, 03056, Ukraine,

e-mail: sergei.peresada@gmail.com

2 - University of Nottingham, NottinghamNG7 2RD, United Kingdom

* ORCID ID : http://orcid.org/0000-0001-8948-722X

** ORCID ID : http://orcid.org/0000-0002-2954-455X

*** ORCID ID : http://orcid.org/0000-0003-2379-5566

**** ORCID ID : http://orcid.org/0000-0002-0508-7198

The concept of experimental investigations of electric vehicles electromechanical systems with hybrid energy storages is designed. Hybrid energy storage system is based on accumulators and supercapacitors. The basic requirements to the functional capabilities of experimental installation have been formulated and installation structure has been developed. A novel DC-DC boost converter control algorithm is presented and experimentally verified. Results of experimental investigation induction motor speed-flux vector control algorithm are presented as well. The designed concept and unified experimental setup can be used to study a wide range of control algorithms used in electric vehicles, including those with battery or supercapacitors 
supply. References 10, figures 5.

Key words: hybrid energy storage system, DC-DC converter, electric vehicles.

Received: 05.03.2018

Accepted: 03.04 .2018

Published: 16.08 .2018

\section{References}

1. Ju, F., Zhang, Q., Deng, W., Li, J. Review of Structures and Control of Battery-Supercapacitor Hybrid Energy Storage System for Electric Vehicles. Proc. IEEE International Conference on Automation Science and Engineering CASE2014. Taipei, 18-22 August 2014. Pp. 143-148. DOI:

https://doi.org/10.1109/CoASE.2014.6899318

2. Beletsky O.A., Suprunovska N.I., Shcherba A.A. Dependences of power characteristics of circuit at charge of supercapacitors on their initial and final voltages. Tekhnichna Elektrodynamika 2016. No 1. Pp. 3-10. (Rus)

3. Biletsky O., Suprunovska N., Shcherba A., The Optimization of Energy Parameters of the Electrical Systems of Charge of Supercapacitor from Accumulator Battery. Proc. $16^{\text {th }}$ International Conference on Computational Problems of Electrical Engineering CPEE2015 . Lviv, 2-5 September 2015. Pp. 4-6. DOI:

https://doi.org/10.1109/CPEE.2015.7333323

4. Sun, L., Feng, K., Chapman, C., Zhang, N. An Adaptive Power Split Strategy for Battery-Supercapacitor Powertrain-Design, Simulation and Experiment. IEEE Transactions on Power Electronics

2017. Vol. 32. No 12. Pp. 9364-9375. DOI: 
https://doi.org/10.1109/TPEL.2017.2653842

5. Bozhko S., Dymko S., Kovbasa S., Peresada S. Maximum Torque-per-Amp Control for Traction IM Drives: Theory and Experimental Results. IEEE Transactions on Industry Applications . 2017. Vol. 53. No 1. Pp. 181-193. DOI: https://doi.or g/10.1109/TIA.2016.2608789

6. Akar, F., Tavlasoglu, Y., Vural, B. An Energy Management Strategy for a Concept Battery/Ultracapacitor Electric Vehicle with Improved Battery Life. IEEE Transactions on Transportation Electrification 2017. Vol. 3. No 1. Pp. 191-200.

DOI:

https://doi.org/10.1109/TTE.2016.2638640

7. Itani, K., De Bernardinis, A., Khatir, Z., Jammal, A., Oueidat, M. Regenerative Braking Modeling, Control, and Simulation of a Hybrid Energy Storage System for an Electric Vehicle in Extreme Conditions. IEEE Transactions on Transportation Electrification. 2016. Vol. 2. No 4. Pp. 465-479.

ps://doi.org/10.1109/TTE.2016.2608763

DOI: htt

8. Kollimalla, S.K., Mishra, M.K., Ukil, A., Gooi, H.B. DC Grid Voltage Regulation Using New HESS Control Strategy. IEEE Transactions on Sustainable Energy. 2017. Vol. 8. No 2. Pp. $772-781$.

g/10.1109/TSTE.2016.2619759

DOI: https://doi.or

9. Peresada, S., Kovbasa, S., Pristupa, D., Pushnitsyn, D., Nikonenko, Y. Nonlinear Control of Voltage Source AC-DC and DC-DC Boost Converters. Bulletin of National Technical University Kharkiv Polytechnic Institute. Problems of Automated Electrodrives

Theory and Practice. Power Electronics and Energy Efficiency

. Kharkiv, 2017. No 27. Pp. 84-88.

10. Peresada, S., Kovbasa, S., Trandafilov, V., Bovkunovych, V. Adaptive to rotor resistance variations vector control of induction motor based on nonlinear separation principle. Tekhnichn a Elektrodynamika

. 2015. No 1. Pp. 43-50. (Rus)

PDF 